\title{
Fire Behaviour of Long Span Composite Floor
}

\author{
JORIS H.H. FELLINGER and L. TWILT \\ Centre for Fire Research \\ TNO Building and Construction Research \\ The Netherlands
}

\begin{abstract}
In scope of the ECSC project Steel Intensive Systems for Shallow Floor Construction a fire test is carried out on a two-span composite flooring system of a continuous composite slab using deep deckings supported on integrated steel beams. The system spans approx. 2 times $4 \times 4 \mathrm{~m}$. In terms of mechanical loading, the degree of utilization of the centre beam amounts 0.5 . Nevertheless, a fire resistance of more than 90 minutes is reached without fire insulation.

The test is simulated successfully with FEM models.

First, 2D thermal models are developed for the beam and the slab separately. The effect of thermal shielding of the slab is taken into account. Moreover, the radiative heat exchange between the upper flange and the web of the decks has been considered as well as the reduced contact between the steel sheets and the concrete cover as developed during the test.

The structural analysis uses material models accounting for temperature dependent yielding of steel and cracking of concrete. The composite action between the beams and the encased concrete is simulated assuming no slip and applying an effective width of the slab of $\mathrm{L} / 4$.
\end{abstract}

\section{KEYWORDS:}

Structural fire design, composite slabs, shallow floors.

\section{INTRODUCTION}

In scope of the European research project Steel Intensive Systems for Shallow Floor Construction a full scale fire test was carried out on a two span composite flooring system at the Centre for Fire research of TNO Building and Construction Research, the Netherlands. The project is cosponsored by the European Coal and Steel Community. The flooring system consists of a 
continuous composite slab using deep steel decks, supported on integrated steel beams, see figs. 1-4. So, the beams are almost completely encased by the slab.

The research project aims at the establishment of design rules for shallow floor systems. The total test programme contains tests at room temperature on separate members and system tests at fire conditions. The design rules will be obtained using numerical models validated by the tests.

This paper descibes one of the fire tests as well as the numerical simulations of this test. In the test, the span of the slab and the beam was $2 \times 3820 \mathrm{~mm}$ and $4600 \mathrm{~mm}$ respectively.

The objective of the test is the demonstration of the benefits of the composite action between the integrated beam and the slab in terms of the fire resistance. Moreover, special attention is paid to the thermal response of the deep decks.

The next paragraph contains a description of the test set up and the global performance. The measurements are treated in comparison with the numerical simulations. The thermal response is presented in paragraph 3, followed by the structural behaviour in paragraph 4 . Finally, paragraph 5 gives the main conclusions.

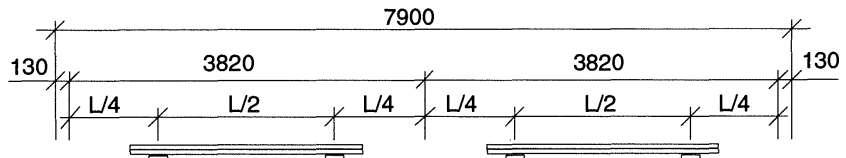

00000000000000000000000000000000

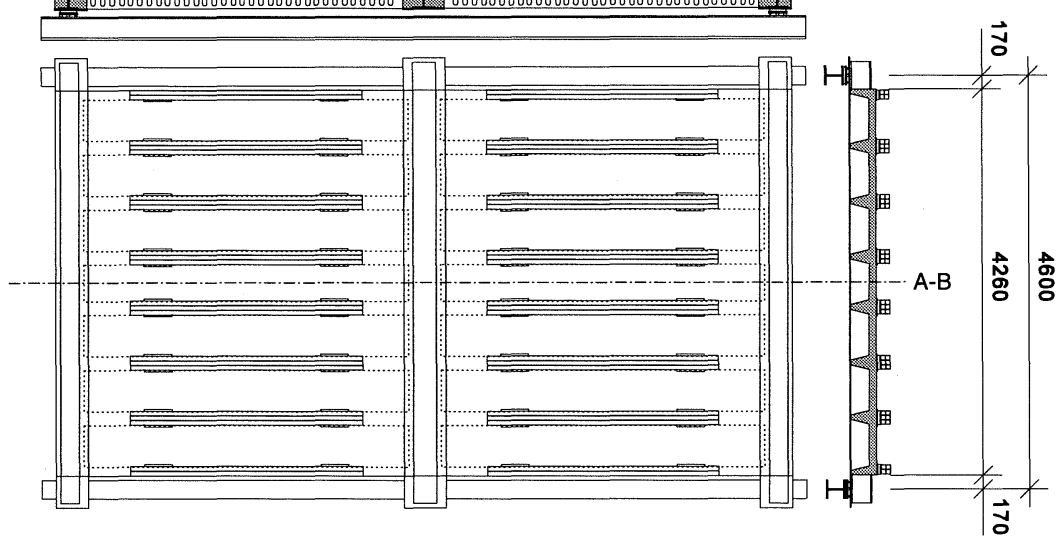

FIGURE 1: Overview of the test specimen

\section{TEST}

\section{Specimen}

The test was performed on a shallow floor system consisting of a continuous composite slab using deep steel deckings supported on integrated steel beams. The slab spanned 2 × $3820 \mathrm{~mm}$ and had 
a width of $4260 \mathrm{~mm}$. The beams spanned $4600 \mathrm{~mm}$, protruding the slab $170 \mathrm{~mm}$ at each side. Figure 1 presents an overview of the test specimen.

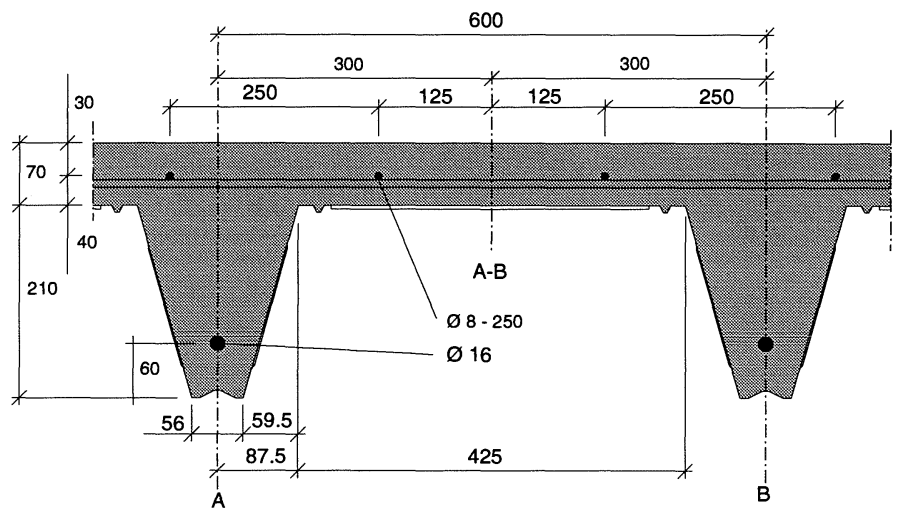

FIGURE 2: Cross section of the slab

The slab consisted of steel sheets CF210/1.00 of PFM Ltd. (UK), $\mathrm{f}_{\mathrm{yd}}=280 \mathrm{MPa}$. The sheeting thickness was $1.0 \mathrm{~mm}$ including a zinc coating of $20 \mu \mathrm{m}$ at both sides. The ribs were $210 \mathrm{~mm}$ deep spacing $600 \mathrm{~mm}$, refer to fig. 2 . On the steel sheets a concrete cover of $70 \mathrm{~mm}$ was casted, resulting in a slab depth of $280 \mathrm{~mm}$. The concrete grade was C35. Each rib was reinforced with one hot rolled bar $\varnothing 16 \mathrm{~mm}$ that was centrally positioned $60 \mathrm{~mm}$ upon the bottom of the sheet. On top of the slab a hand made hot rolled mesh $\varnothing ~ 8-250$ was placed continuous over the centre beam. The mesh had a cover of $26 \mathrm{~mm}$. All reinforcement was of grade FeB $500 \mathrm{HWL}$.

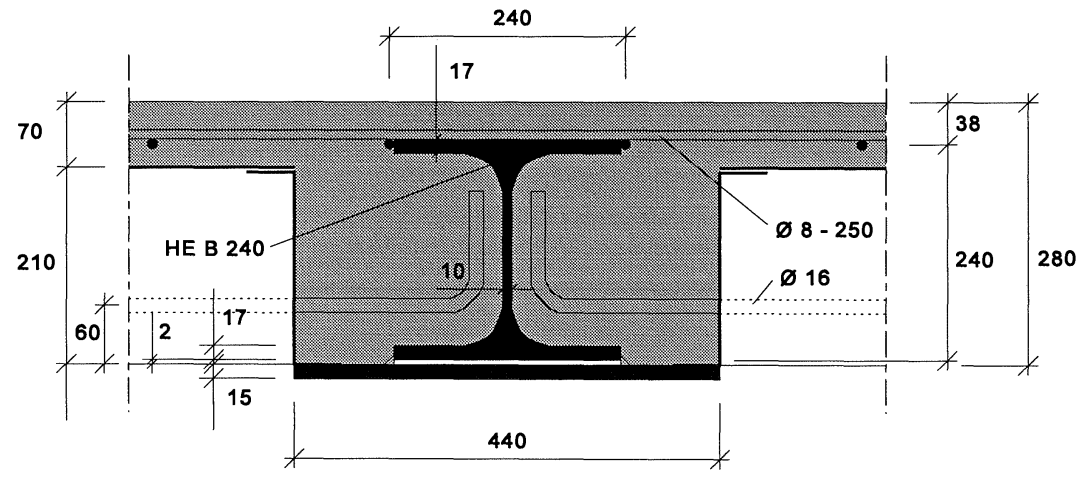

FIGURE 3: Cross section of the centre beam

The centre beam consisted of a hot rolled steel section HE $240 \mathrm{~B}$ that was welded on a protruding bottom plate of $440 \times 15 \mathrm{~mm}$, see fig. 3. Between the lower flange and the bottom plate of the 
centre beam a well defined gap of $2 \mathrm{~mm}$ was introduced, using iron chords parallel to the welds. These chords were melted into the welds.

The edge beams consisted of hot rolled steel sections HE $200 \mathrm{~B}$, asymmetrically welded on a bottom plate of $330 \times 15 \mathrm{~mm}$, see fig. 4 . The minimal size of the fillet weld was $5 \mathrm{~mm}$. No air gap was introduced between the bottom plate and the lower flange of the edge beam.

The steel quality of all beams was FeE 235 (both I-sections and plates).

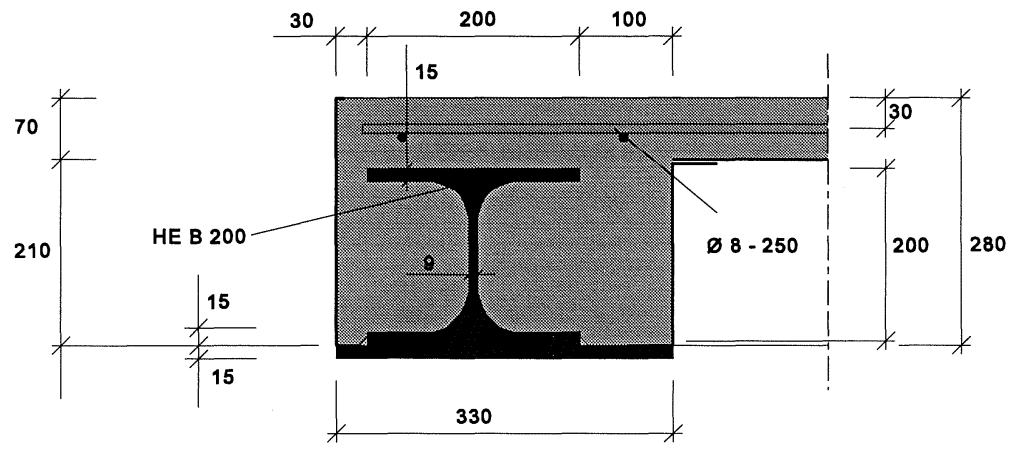

FIGURE 4: Cross section of the edge beams

\section{Material properties}

The concrete was casted in two batches. The concrete strength of each batch was measured using six cubes $150 \times 150 \times 150 \mathrm{~mm}$, three of which were tested after 28 days. The other three cubes were tested at the day of the fire test. The results are summarized in table 1.

The moisture contents was determined with three concrete samples that were shaped identical to the test specimen, i.c. the same steel sheet was used with the same cover. The size was restricted to two ribs and a length of $400 \mathrm{~mm}$. The vertical sides were sealed to avoid drying from these surfaces. The moisture content was determined on the day of the fire test and amounted $4.11 \%$.

Table 1: Concrete strength measured from 12 cubes $150 \times 150 \times 150 \mathrm{~mm}$.

\begin{tabular}{|c|c|c|c|c|c|c|c|c|}
\hline $\begin{array}{l}\text { Batch } \\
\text { No. }\end{array}$ & $\begin{array}{l}\text { Curing } \\
\text { days }\end{array}$ & $\begin{array}{l}\mathrm{f}_{c}^{\prime} \\
\mathrm{MPa}\end{array}$ & $\begin{array}{l}\text { Density } \\
\mathrm{kg} / \mathrm{m}^{3}\end{array}$ & $\begin{array}{l}\text { Batch } \\
\text { No. }\end{array}$ & $\begin{array}{l}\text { Curing } \\
\text { days }\end{array}$ & $\begin{array}{l}\mathrm{f}_{\mathrm{c}}^{\prime} \\
\mathrm{MPa}\end{array}$ & $\begin{array}{l}\mathrm{f}_{\mathrm{c}} \\
\mathrm{MPa}\end{array}$ & $\begin{array}{l}\text { Density } \\
\mathrm{kg} / \mathrm{m}^{3}\end{array}$ \\
\hline \multirow{3}{*}{1} & \multirow{6}{*}{28} & 44.9 & 2361 & \multirow{3}{*}{1} & \multirow{6}{*}{163} & 55.7 & & 2318 \\
\hline & & 45.4 & 2375 & & & 56.3 & & 2329 \\
\hline & & 46.3 & 2376 & & & & 5.36 & 2301 \\
\hline \multirow{3}{*}{2} & & 40.5 & 2356 & \multirow{3}{*}{2} & & 41.1 & & 2295 \\
\hline & & 40.2 & 2368 & & & 43.0 & & 2321 \\
\hline & & 39.6 & 2379 & & & & 4.27 & 2293 \\
\hline Average & 28 & 42.8 & 2369 & Average & 163 & 49.0 & 4.82 & 2310 \\
\hline
\end{tabular}


The yield stress and the tensile strength of the steel sheets were measured on three samples of $50 \times 12.5 \mathrm{~mm}$. Table 2 presents the results. The mechanical properties of the rib rebars and the mesh reinforcement were measured on samples of $300 \mathrm{~mm}$, see table 3 . To measure the steel quality of the centre beam a strip was cut out of the lower flange and the plate, near the support. No samples were obtained from the edge beams. The results are given in table 2 .

\section{Support system}

In order to avoid membrane action, the edge beams were supported on rollers in both directions. The centre beam support was designed as a roller in the beam axis direction and as a hinge in the slab axis direction. The centre beam was suspended in a frame to enable the measurement of the support reaction with a load cell, sufficiently far away from the heated environment.

Table 2: Dimensions and properties of the beams and the steel sheet

\begin{tabular}{|c|c|c|c|c|c|c|c|c|c|c|}
\hline \multirow{2}{*}{\multicolumn{2}{|c|}{$\begin{array}{l}\text { Section serial size and } \\
\text { type }\end{array}$}} & \multirow{2}{*}{$\begin{array}{c}\text { Depth } \\
\text { of } \\
\text { section } \\
\text { mm }\end{array}$} & \multicolumn{2}{|c|}{$\begin{array}{c}\text { Width of } \\
\text { section } \mathrm{mm}\end{array}$} & \multicolumn{3}{|c|}{$\begin{array}{c}\text { Thickness } \\
\text { mm }\end{array}$} & \multirow[t]{2}{*}{$\begin{array}{c}\mathbf{f}_{\mathrm{y}} \\
\mathrm{MPa}\end{array}$} & \multirow[t]{2}{*}{$\begin{array}{c}\mathbf{f}_{\mathrm{u}} \\
\mathrm{MPa}\end{array}$} & \multirow[t]{2}{*}{$\begin{array}{l}\varepsilon_{\mathrm{u}} \\
\%\end{array}$} \\
\hline & & & $\begin{array}{l}\text { upper } \\
\text { flange }\end{array}$ & $\begin{array}{l}\text { lower } \\
\text { flange }\end{array}$ & $\begin{array}{l}\text { upper } \\
\text { flange }\end{array}$ & $\begin{array}{l}\text { lower } \\
\text { flange }\end{array}$ & web & & & \\
\hline \multicolumn{2}{|l|}{ HE $240 \mathrm{~B}$} & 239 & 239 & 241 & 16.3 & 16.6 & 9.4 & 239.2 & 389.9 & 39.5 \\
\hline \multicolumn{2}{|l|}{ Plate $440 \times 15$} & & \multicolumn{2}{|c|}{441} & \multicolumn{3}{|c|}{15.0} & 279.3 & 402.2 & 34.6 \\
\hline HE $200 \mathrm{~B}$ & \multirow{2}{*}{ I } & 203 & 201 & 200 & 12.3 & 12.5 & 7.4 & & & \\
\hline Plate $330 \times 15$ & & & \multicolumn{2}{|c|}{330} & \multicolumn{3}{|c|}{14.0} & & & \\
\hline HE $200 \mathrm{~B}$ & \multirow{2}{*}{ II } & 202 & 200 & 201 & 12.5 & 12.7 & 7.6 & & & \\
\hline Plate $330 \times 15$ & & & \multicolumn{2}{|c|}{330} & \multicolumn{3}{|c|}{24.0} & & & \\
\hline \multirow{3}{*}{ Steel sheet } & a & & & & \multicolumn{3}{|c|}{0.955} & 361 & 434 & \\
\hline & b & & & & \multicolumn{3}{|c|}{0.943} & 355 & 436 & \\
\hline & c & & & & \multicolumn{3}{|c|}{0.953} & 347 & 431 & \\
\hline
\end{tabular}

Table 3: Properties of the rib rebars and the mesh reinforcement.

\begin{tabular}{|l|c|l|l|l|l|l|}
\hline Reinforcement & Diameter mm & Area $\mathrm{mm}^{2}$ & $\mathrm{f}_{\mathrm{y}} \mathrm{MPa}$ & $\mathrm{f}_{\mathrm{u}} \mathrm{MPa}$ & $\varepsilon_{\mathrm{u}} \%$ \\
\hline \multirow{3}{*}{ Rib $\varnothing 16 \mathrm{~mm}$} & $\mathrm{a}$ & 16.1 & 204 & 565 & 653 & 9.6 \\
\cline { 2 - 8 } & $\mathrm{b}$ & 16.1 & 204 & 572 & 658 & 10.3 \\
\hline \multirow{2}{*}{ Mesh $\varnothing 8 \mathrm{~mm}$} & $\mathrm{a}$ & 8.0 & 50.7 & 568 & 631 & 11.5 \\
\cline { 2 - 7 } & $\mathrm{b}$ & 8.0 & 50.3 & 628 & 694 & 10.2 \\
\hline
\end{tabular}

\section{Loading}

A degree of utilization, defined as the ratio between the applied load and the load bearing capacity 
at room temperature, of 0.5 for the centre beam was applied. The bending moment capacity is calculated at $304 \mathrm{kNm}$ based on the non-composite cross section only. An load of $302.4 \mathrm{kN}$ is imposed using dead weight of massive steel blocks positioned above the ribs at $1 / 4 \mathrm{~L}$ and $3 / 4 \mathrm{~L}$ of the slab span, see fig. 1.

\section{General behaviour}

At 24 March 1995, the specimen was subjected to the ISO 384 standard fire curve [1] during 93 minutes without failure. At the end the deflection of the slab at midspan was $300 \mathrm{~mm}$ and the deflection rate was approx. $5 \mathrm{~mm} / \mathrm{min}$. After 93 minutes the beam deflected $270 \mathrm{~mm}(\mathrm{~L} / 17)$. Table 4 shows the fire resistance with respect to the load bearing capacity for various deformation criteria and the thermal insulation. No integrity failure was observed.

Table 4: Fire resistance depending on criterium applied.

\begin{tabular}{|l|c|c|c|c|c|c|}
\hline \multirow{2}{*}{ Criterium } & \multicolumn{4}{|l|}{ Thermal insulation } & \multicolumn{4}{l|}{ Load bearing capacity } \\
\cline { 2 - 7 } & $\mathrm{avg}=+140^{\circ} \mathrm{C}$ & $\max =+180^{\circ} \mathrm{C}$ & $\mathrm{d}=\mathrm{L} / 30$ & $\mathrm{~d}=\mathrm{L} / 20$ & $\mathrm{~d} /[\mathrm{min}]=\mathrm{L}^{2} / 400 \mathrm{~d}$ & $\mathrm{~d}=\mathrm{L} / 15$ \\
\hline $\begin{array}{l}\text { fire resistance } \\
{[\text { min] }}\end{array}$ & $>93$ & 93 & 67 & 83 & 73 & $>93$ \\
\hline
\end{tabular}

\section{3}

\section{THERMAL RESPONSE}

The fire test was simulated using DIANA, a general purpose Finite Element Method programme [2], using an Euler backwards iteration process.

The temperatures in the centre beam and the slab were calculated separately by means of $2 \mathrm{D}$ models of the cross section. These models sufficed since the temperature measurements showed that the thermal gradient along the beam axis was negligible.

No separate simulations were done for the edge beams, since the measured temperatures in the edge beams hardly differed from the temperatures in the centre beam.

\section{General assumptions}

1. The thermal properties of steel and concrete were taken from Eurocode 4 [3], including the heating and evaporation of moisture in concrete.

2. Heating from the lower side according to ISO 384 standard fire curve.

3. Convection: exposed side $25 \mathrm{~W} / \mathrm{m}^{2} \mathrm{~K}$, unexposed side $8 \mathrm{~W} / \mathrm{m}^{2} \mathrm{~K}$, between the ribs of the slab $12 \mathrm{~W} / \mathrm{m}^{2} \mathrm{~K}$.

4. Emissivity: Concrete 0.78 , steel beam 0.6 , steel sheets $0.09\left(\leq 250^{\circ} \mathrm{C}\right)-0.4\left(\geq 800^{\circ} \mathrm{C}\right)$ accounting for the melting of the zinc coating.

\section{Centre beam}

Only one half of the cross section needed to be modelled in view of symmetry, see fig. 5 . The air 
gap between the bottom plate and the lower flange that was intensionally introduced to improve the prediction of the thermal resistance in between, is modelled by defining a void taking into account the conduction of air and the radiation between the envelope of steel surfaces.
Mesh of the centre beam

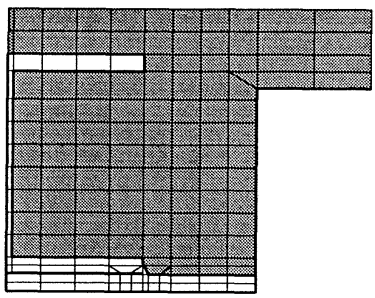

Mesh of the slab

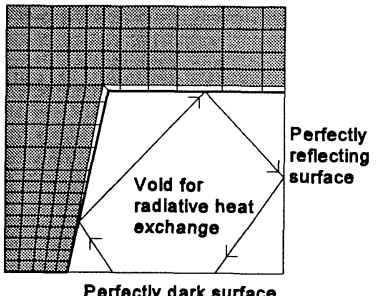

Perfectly dark surface

FIGURE 5: Meshes used to simulate the thermal response.

Figure 6 shows the

temperatures. The calculation is in good agreement with the measured temperatures.

\section{Slab}

The slab model made use of the two lines of symmetry of the slab, in the heart of the rib and in the middle between two ribs respectively. The web and the upper flange of the steel sheet were exposed to a lesser heating. Moreover, the heating depended on the radiative heat exchange between these surfaces. These effects are incorporated by modelling a void closed by a perfectly dark surface with a temperature according to ISO 384 and a perfectly reflecting surface at the line of symmetry between two ribs.

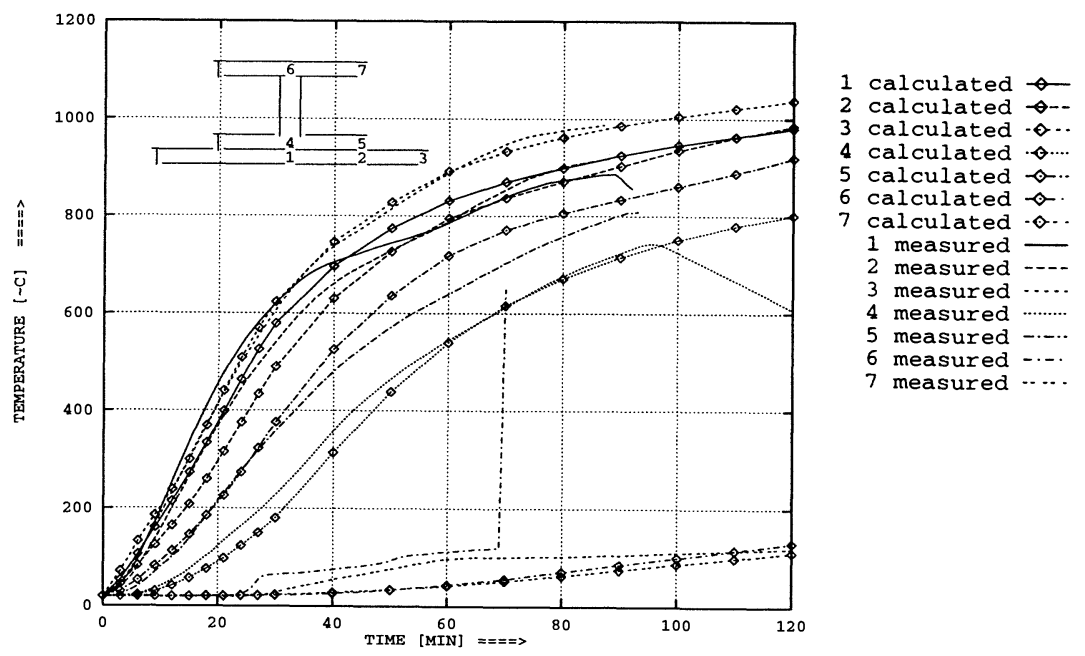

FIGURE 6: Temperatures of the centre beam between two ribs: calculated vs measured.

The sudden increase of the temperature difference between the steel sheet (upper flange and web) and the concrete cover that was measured between $15-20$ minutes at approx. $100^{\circ} \mathrm{C}$, indicated that the contact between the steel sheet and the cover deteriorated, see fig. 8 . The evaporation of 
moisture could have affected this loss of contact. After the test a gap between the sheet and the cover is also observed. As will be treated in the next paragraph, preliminary structural analyses of the floor system showed that a proper temperature calculation of the steel sheets is of great importance for the thermal gradient of the slab and thus for the global load redistribution. To simulate the thermal response of the slab, a void is modelled between the steel sheet and the concrete cover, incorporating radiative heat transfer and conduction of air. Up to $100{ }^{\circ} \mathrm{C}$ no thermal resistance of this air layer is assumed, by setting the conduction of air at infinity.

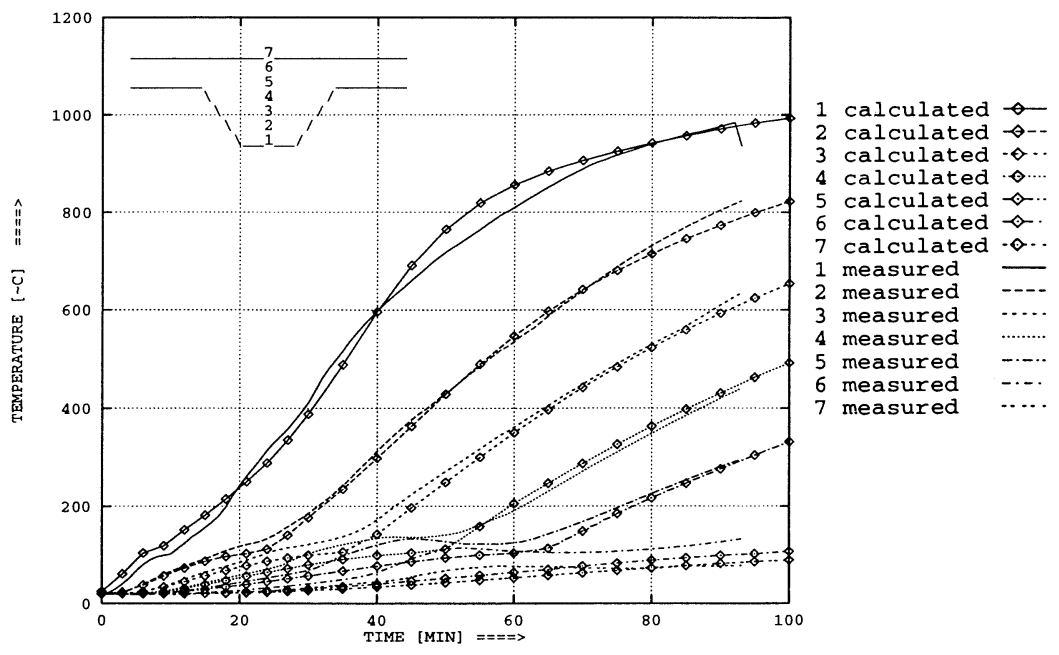

FIGURE 7: Temperatures over the height of the rib.

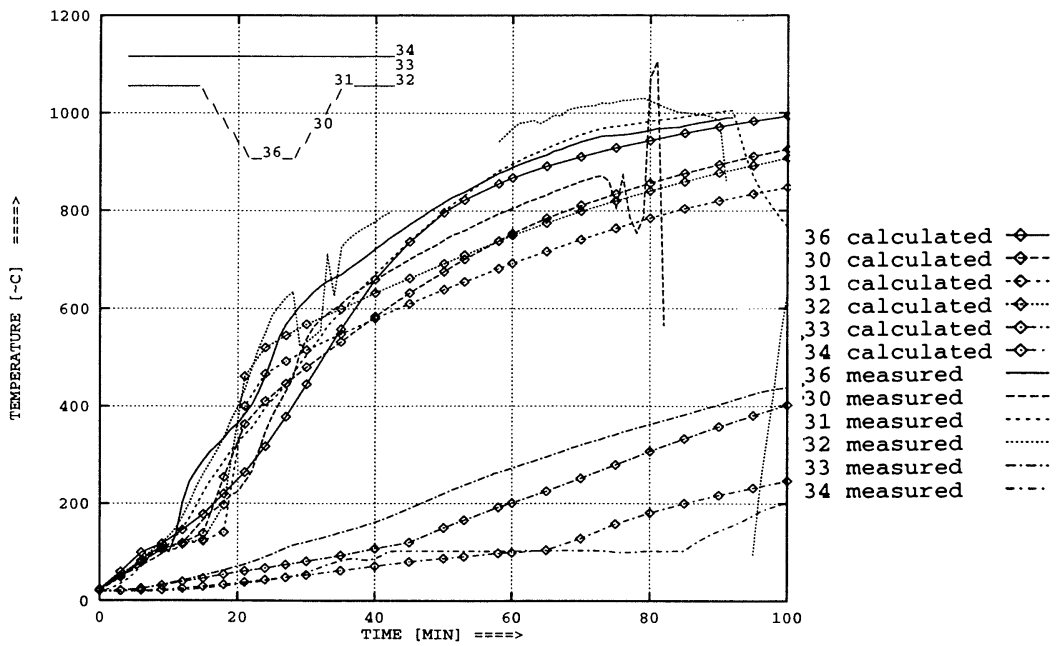

FIGURE 8: Temperatures along the steel sheet, comparison with span II 
Figure 7 compares the measured temperatures in the rib with the simulations. The agreement is good, which is mainly of importance for the temperatures of the rib rebar, referring to point no. 2. The temperatures along the steel sheet and in the concrete cover between two ribs are compared with the measurements in one span, see fig. 8 .

The simulations agree well with the measurements relative to the large variation in the measurements between the spans, caused by the unpredictable loss of contact between the steel sheet and the cover.

\section{STRUCTURAL BEHAVIOUR}

In view of symmetry only one half of one slab span needed to be modelled. The centre beam and the edge beam were modelled with quadratic beam elements. Each rib of the slab was modelled with these beam elements as well, see figure 9. The simulations were performed using the BFGS iteration method [4].

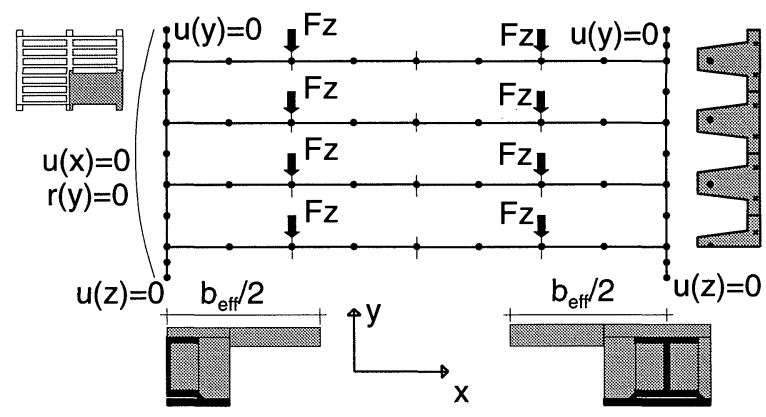

FIGURE 9: Overview of the mesh used for the structural response. The z-direction is perpendicular to the drawing plane.

\section{Assumptions}

The concrete part and the steel part of a cross section were modelled within the same beam element, thus assuming full composite interaction. No plate action was taken into account because the slab was modelled with separate beam elements for each ribs without longitudinal joints. The composite action between the slab and the beam was considered by taking into account an effective width $b_{\text {eff }}$ for the beam, see fig.9.

The temperature dependent mechanical properties including yielding of steel and cracking of concrete were taken from Eurocode 4 accounting for the measured values at room temperature. To avoid numerical instability yielding of concrete is not taken into account. According to Jaarsveld [5] this simplification gives small errors.

The calculation was based on the temperature simulations as presented in the previous paragraph. Besides, for the effective width was assumed: $\mathrm{b}_{\text {eff }}=\mathrm{L}_{\text {beam }} / 4$. 


\section{Results}

The measured support reaction is compared with the simulations in figure 10. Calculation 2 refers to the simulation based on the above mentioned assumptions. The agreement is very good. The deflections are given in figure 11. In the first hour, the simulation is in accordance with the measurements. The second hour the calculation diverges from the test. This might be caused by the shear deformation in the test, which is not included in the beam elements of the FEM programme. After the 85 minutes the simulation is unreliable due to numerical instability.

Calculation 1 refers to preliminary analyses. These preliminary analyses were carried out on basis of temperatures of the slab calculated without a thermal resistance between the steel sheet and the concrete cover and assuming an effective width $\mathrm{b}_{\text {eff }}=\mathrm{L}_{\text {beam }} / 7$.

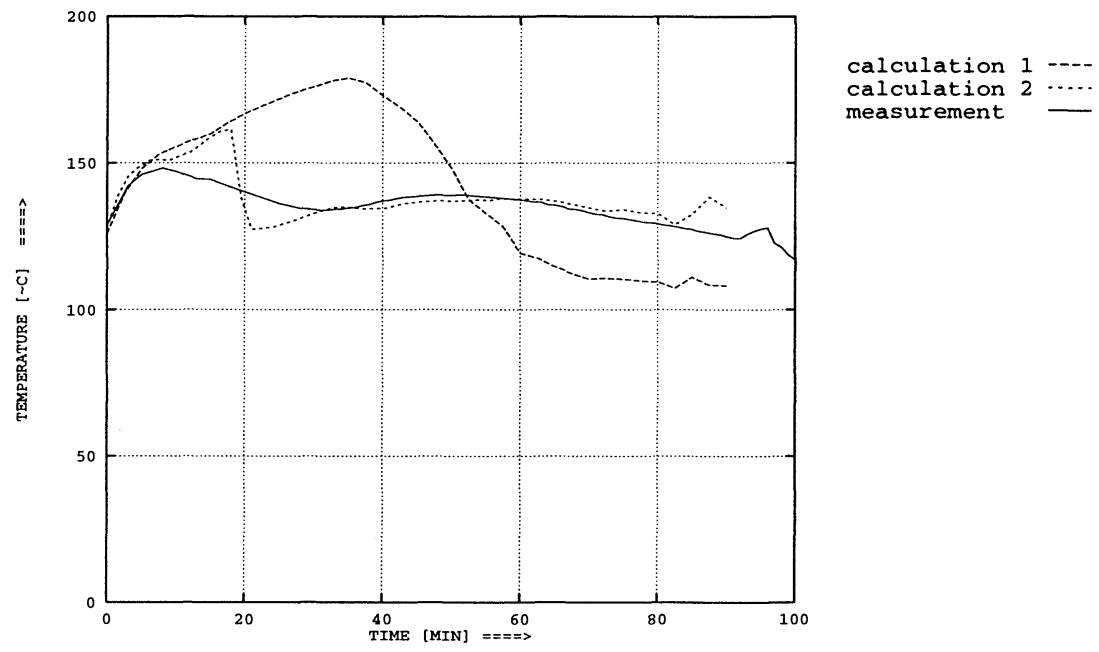

FIGURE 10: Support reaction force of the centre beam. Calculated vs measured.

As fig. 10 shows, the preliminary analyses overestimate the support reaction in the first hour, indicating an overestimated thermal gradient in the slab. Because full contact was modelled between the steel sheet and the concrete cover in the thermal model, the temperatures of the upper flange of the steel sheet were underestimated, and thus the thermal gradient in the slab was overestimated. In this simulation the slab spread too much load to the centre beam. In the second hour the support reaction is underestimated. Thus, the assumed effective width is too small.

\section{CONCLUSIONS}

The bare steel construction consisting of a two span continuous composite slab supported on integrated steel beams reached a fire resistance of more than 90 minutes in a full scale standard fire test. Analysing the thermal response, the partial protection of the web and the upper flange of the slab was considered as well as the loss of the contact between the steel sheet and the concrete cover. The temperature dependent thermal properties of both steel and concrete were 
taken into account according to Eurocode 4.

The structural behaviour was analysed assuming full composite action both in the beam between the steel section and the concrete cover as well as in the slab between the steel sheet and the concrete cover. The interaction between beam and slab could be simulated applying an effective width $\mathrm{L}_{\text {beam }} / 4$.The temperature dependent mechanical properties of both steel and concrete according to Eurocode 4 were taken into account. The FEM simulations of both the thermal and structural response of the flooring system were satisfactory.

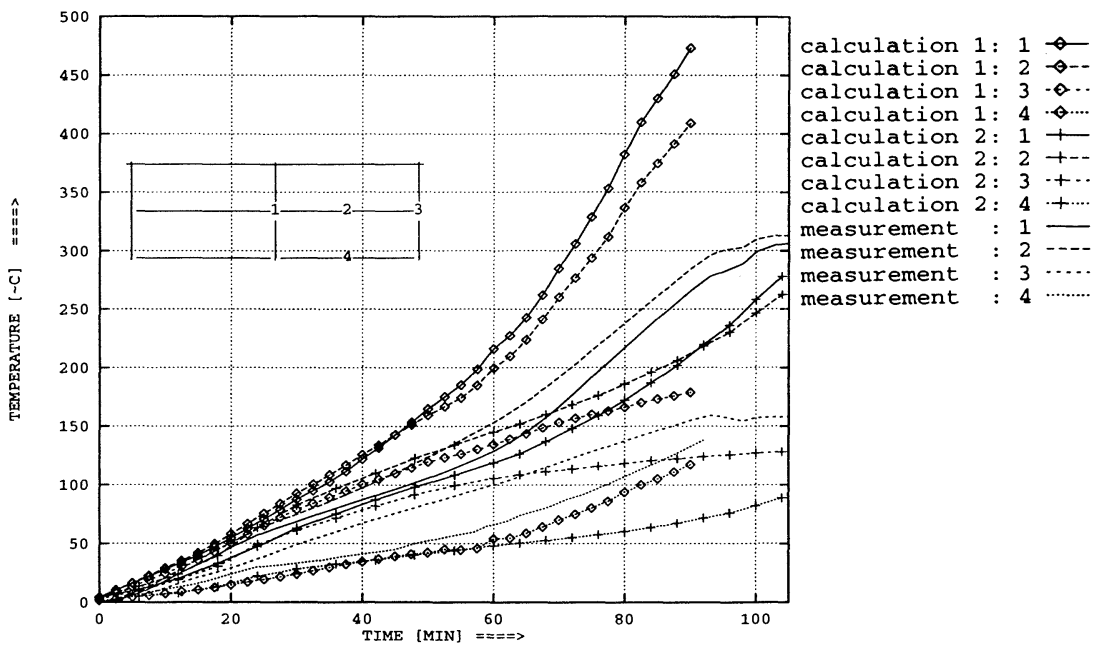

FIGURE 11: Vertical displacements in four points: calculations vs measurements.

\section{ACKNOWLEDGEMENTS}

The financial support of the European Coal and Steel Community, under grant ECSC-Agreement $7210 / \mathrm{SA} / 621$ is gratefully acknowledged.

\section{REFERENCES}

1. ISO 384, Fire Resistance Tests - Elements of Building Construction - Part 1: General Requirements for Fire Resistance Testing, Draft ISO TC92/SC2/WG1, 1990

2. DIANA User's Manual, Volume 7: Potential Flow Analysis, TNO Release 5.1, Revision A, Delft, April 1993

3. Eurocode 4, Design of Composite Steel and Concrete Structures, part 1.2: Structural Fire Design, ENV 1994-1-2, April 1994

4. DIANA User's Manual, Volume 4: Nonlinear Analysis, TNO Release 5.1, Revision A Delft, April 1993 
5. Jaarsveld, E.P., Validation of Beam Elements, TU Delft 25.2.91-2.16 / TNO report BI-91149, Delft, September 1991. (In Dutch)

6. Fellinger, J.H.H., Van de Haar, P.W., Steel intensive Systems for Shallow Floor Construction: Part 1: Test Data, ECSC-Agreement 7210/SA/621, TNO report 95-CVBR0708, Delft, June 1995

7. Fellinger, J.H.H. \& Van de Haar, P.W., Steel intensive Systems for Shallow Floor Construction: Part 2: Numerical simulations, ECSC-Agreement 7210/SA/621, TNO report 95-CVB-R0765, Delft, October 1995 